\title{
Disease prevalence among young dogs in Grand Tunis, Tunisia: A retrospective study
}

\author{
Ghada Tagorti \\ Department of Small Animal Medicine and Surgery, National School of Veterinary Medicine, Manouba University, \\ 2020 Sidi Thabet, Tunisia. \\ Corresponding author: Ghada Tagorti, e-mail: tagortig@gmail.com \\ Received: 08-12-2018, Accepted: 18-02-2019, Published online: 02-04-2019
}

doi: 10.14202/vetworld.2019.489-495 How to cite this article: Tagorti G (2019) Disease prevalence among young dogs in Grand Tunis, Tunisia: A retrospective study, Veterinary World, 12(4): 489-495.

\begin{abstract}
Aim: A retrospective study was undertaken to determine the occurrence, and the distribution of the most common clinical conditions of young dogs encountered at the National School of Veterinary Medicine clinic, Tunisia, from September 2012 to July 2013, based on sex, age, breeds, and season variation.

Materials and Methods: A total of 515 cases were examined, and 11 clinical conditions were recorded. Clinical examination was performed. X-ray examination and necropsy were carried out only when needed.

Results: Of the 515, 298 cases (57.86\%) were male, while 217 (42.14\%) were female. The breed-wise difference in the occurrence of various health problems was statistically significant. Nevertheless, no significant association was found between the occurrence of a disease and age. The commonly found clinical conditions were traumatic injuries $(22.72 \%)$, ectoparasitic infections (20.58\%), and gastroenteritis $(13.40 \%)$. The occurrence of diseases was the highest $(60.19 \%)$ in the wet season (September-February) followed by $39.81 \%$ in the dry season (March-July).
\end{abstract}

Conclusion: The current study presents the first recorded data about the major clinical conditions of young dogs in Tunisia. These findings can be used to develop more effective disease management and control strategies.

Keywords: disease, dog, epidemiology, juvenile, prevalence, Tunisia.

\section{Introduction}

Domestic dog is the most widespread, abundant, and sociable canids. Since 15,000 years ago, the relationship between dogs and humans has been mutually beneficial [1]. Domestic dogs were kept as social companions and/or working services (e.g., hunting dogs, guardian dogs, therapy dogs, and police dogs) [2]. Currently, the dog breeding increased, to reach in 2016 more than 671 thousand dogs in Tunisia [3]. Thus, dogs often go beyond the boundaries of the house to develop animal instincts and prevent undesirable behavior correlated to stress and poor welfare [4]. As a result, environmental conditions will affect the ability of dogs to cope with change. Therefore, dogs will face health issue and disease management, especially during the juvenile stage while the immune system is immature and of weak efficacy [5]. In addition, the heterogeneity of purebreds creates a great diversity on the function of the immune system between various canine breeds [6]. With such background, the interaction of young dogs toward pathogen agent and the environment is specific to each, and these components can shift the balance toward or away from emerging diseases.

Copyright: Tagorti. Open Access. This article is distributed under the terms of the Creative Commons Attribution 4.0 International License (http://creativecommons.org/licenses/by/4.0/), which permits unrestricted use, distribution, and reproduction in any medium, provided you give appropriate credit to the original author(s) and the source, provide a link to the Creative Commons license, and indicate if changes were made. The Creative Commons Public Domain Dedication waiver (http://creativecommons.org/ publicdomain/zero/1.0/) applies to the data made available in this article, unless otherwise stated.
On the other hand, the Grand Tunis, which is defined geographically as the area including four governorates (Ben Arous, Tunis, Ariana, and Manouba) located in the North of Tunisia, is characteristically semi-arid with a mild winter. These climatic conditions are generally conducive for infectious diseases. Consequently, there has been a good deal of research conducted on companion animal diseases. However, the majority had focused on the surveillance and control of diseases in adult dogs.

Hence, to reduce the gap in our knowledge of the distribution of clinically important diseases of young dogs, this retrospective study was carried out to evaluate the major disease conditions diagnosed at the National School of Veterinary Medicine clinic. This study is the first to report on disease profiles of juvenile dogs in Tunisia.

\section{Materials and Methods}

The retrospective data were retrieved from the clinical case records of owned dogs of the National School of Veterinary Medicine clinic, located in the Ariana Governorate in Tunisia (longitude $10^{\circ} 2^{\prime} 52.587^{\prime \prime} \mathrm{E}$ and latitude $36^{\circ} 54^{\prime} 26.219^{\prime \prime} \mathrm{N}$ ) from September 2012 to July 2013. A total number of 515 young dogs aged under 7 months (juvenile phase) were recorded from 2291 dogs overall after the exclusion of cases for routine deworming and vaccinations. The distribution patterns of cases were according to sex, age, breeds, and season (August is not included due to summer break) to represent the 
Grand Tunis area. Diagnosis was based on history, physical examination, clinical signs, and sometimes postmortem findings. Detailed clinical examination was performed using visual examination, rectal temperature, pulse, respiration rates, and examination of different organs and systems using palpation, percussion, and auscultation when needed [7]. Extension and flexion, needle puncture, ophthalmic, and X-ray examination were also performed when required. For diagnostic purposes, fecal samples, skin scrapings, blood, and urine samples were examined. Necropsy was carried out on dead young dogs to record the gross lesions.

\section{Statistical analysis}

Data were summarized, reported as percentages, and subjected to Fisher's exact test. All analyses were performed with analytical software (SPSS version 20.0, SPSS Inc., Chicago, IL, USA). Values of $\mathrm{p} \leq 0.05$ were considered as statistically significant.

\section{Results and Discussion}

The present study had given an overall idea about the prevalence of the most commonly occurring juvenile canine diseases presented at the National School of Veterinary Medicine clinic in Tunisia during the period going from September 2012 to July 2013. The juvenile problems had an overall prevalence of $22.5 \%$ during this period. Similar findings were reported in a study in Bangladesh, and the recorded prevalence was $36.1 \%$ [8]. The highest incidence of juvenile affections was recorded in the males $(57.86 \%)$, with $42.14 \%$ of cases for females $(\mathrm{p}=0.012)$. This finding may coincide with the pet owner preference and gender stereotypes. It was hypothesized that men with their masculinity and independence characteristics predicted a preference for male dogs [9]. Of 515 young dogs presented with different clinical conditions, $286(55.53 \%)$ were aged between 1 and 3 months as compared to the group aged more than 3 months (44.47\%). However, the analysis showed no statistically significant association between age group and clinical conditions. To depict the morbidity profile by breeds of young dogs, a total of eight breeds were recorded as the most common in the studied area. Therefore, breed-specific proportional morbidity rates revealed that American Staffordshire Terrier (27.18\%), German Shepherd (18.25\%), mixed breed (14.56\%), Rottweiler (12.43\%), Poodle (5.83\%), Spaniel (6.02\%), and Labrador (4.47\%) were affected (Table-1). This observed incidence could be related to the population distribution based on the upsurge in the acquisition of these specific breeds for security or breeding purposes. Besides, selective breeding and the repeated use of popular sires could have increased the susceptibility of developing diseases in domestic dogs [10]. In the current study, of 515 young dogs, 11 clinical conditions were diagnosed, representing infectious diseases $(51.07 \%)$ followed by non-infectious (35.53\%) and non-specific diseases or diseases with multiples causes (13.4\%) (Figure-1). Consequently, infectious diseases were the major causes of young dogs' diseases with predominantly ectoparasitic $(20.58 \%)$ and endoparasitic infections (11.65\%). In addition, traumatic injuries $(22.72 \%)$ and nutritional secondary hyperparathyroidism (NSH) $(7.77 \%)$ were the

Table-1: Breed distribution of clinical conditions of young dogs.

\begin{tabular}{|c|c|c|c|c|c|c|c|c|c|c|}
\hline \multirow{2}{*}{$\begin{array}{l}\text { Clinical } \\
\text { condition }\end{array}$} & \multirow{2}{*}{$\begin{array}{c}\text { Total } \\
\text { n (\%) }\end{array}$} & \multicolumn{8}{|c|}{ Breeds } & \multirow[t]{2}{*}{ p-value } \\
\hline & & $\begin{array}{c}\text { American } \\
\text { Staffordshire } \\
\text { terrier }\end{array}$ & G.S & Spaniel & Poodle & Mixed & Rottweiler & Labrador & Others & \\
\hline \multicolumn{11}{|l|}{ Infectious } \\
\hline Parvovirosis & $54(10.49)$ & 13 & 33 & 2 & 0 & 0 & 6 & 0 & 0 & $0.000 *$ \\
\hline Ehrlichiosis & $11(2.14)$ & 9 & 0 & 0 & 0 & 0 & 2 & 0 & 0 & $0.005 *$ \\
\hline RT infections & $5(0.97)$ & 0 & 0 & 0 & 0 & 0 & 1 & 3 & 1 & 0.907 \\
\hline Eye disorders & $27(5.24)$ & 4 & 2 & 2 & 3 & 2 & 4 & 4 & 6 & 0.975 \\
\hline Endoparasitic I & $60(11.65)$ & 20 & 6 & 6 & 0 & 12 & 12 & 0 & 4 & $0.000 *$ \\
\hline Ectoparasitic I & $106(20.58)$ & 30 & 13 & 5 & 6 & 22 & 13 & 5 & 12 & $0.009 *$ \\
\hline Subtotal & $263(51.07)$ & 76 & 54 & 15 & 9 & 36 & 38 & 12 & 23 & \\
\hline \multicolumn{11}{|l|}{ Non-infectious } \\
\hline Hip dysplasia & $11(2.14)$ & 1 & 8 & 0 & 0 & 0 & 2 & 0 & 0 & $0.027^{*}$ \\
\hline $\begin{array}{l}\text { Traumatic } \\
\text { injuries }\end{array}$ & $117(22.72)$ & 29 & 12 & 7 & 13 & 26 & 12 & 3 & 15 & $0.000 *$ \\
\hline $\mathrm{NSH}$ & $40(7.77)$ & 16 & 10 & 4 & 0 & 3 & 4 & 0 & 3 & $0.006 *$ \\
\hline $\begin{array}{l}\text { Congenital } \\
\text { anomalies }\end{array}$ & $15(2.91)$ & 5 & 0 & 1 & 0 & 3 & 1 & 2 & 3 & 0.826 \\
\hline Subtotal & $183(35.54)$ & 51 & 30 & 12 & 13 & 32 & 19 & 5 & 21 & \\
\hline \multicolumn{11}{|l|}{ Non-specific } \\
\hline Gastroenteritis & $69(13.40)$ & 13 & 10 & 4 & 8 & 7 & 7 & 6 & 14 & 0.687 \\
\hline Subtotal & $69(13.40)$ & 13 & 10 & 4 & 8 & 7 & 7 & 6 & 14 & 0.687 \\
\hline Grand total & $515(100.00)$ & 140 & 94 & 31 & 30 & 75 & 64 & 23 & 58 & $0.000 *$ \\
\hline
\end{tabular}

G.S = German Shepherd, RT = Respiratory tract, NSH = Nutritional secondary hyperparathyroidism, I = Infections. Asterisks $(*)$ indicate a significant association 
most common non-infectious diseases reported. Gastroenteritis represented the non-specific group with $13.40 \%$ of clinical cases. Nevertheless, lower prevalence of infectious and non-infectious diseases was recorded by earlier studies $[8,11]$. This variation may be due to different geographical regions and periods. In addition, diseases were prominent in the wet season $(60.19 \%)$ due to the multiplication of etiologic agents in these environmental conditions (Figure-2).

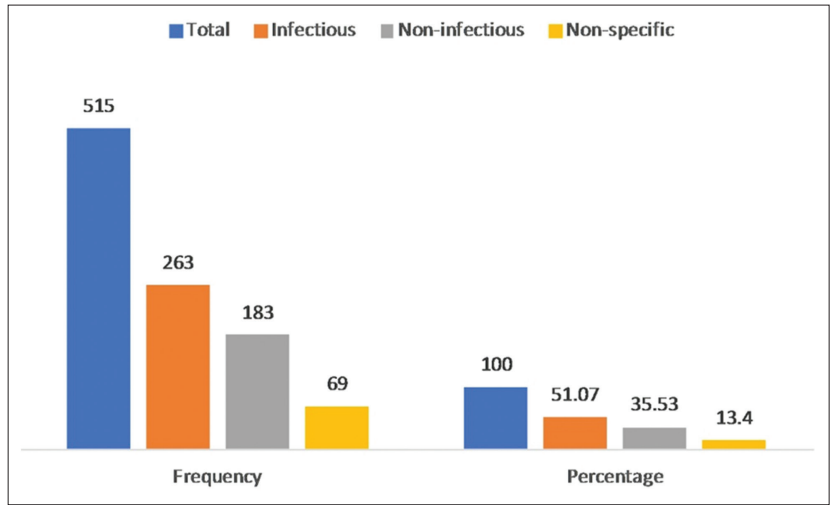

Figure-1: Classification of clinical conditions of young dogs.

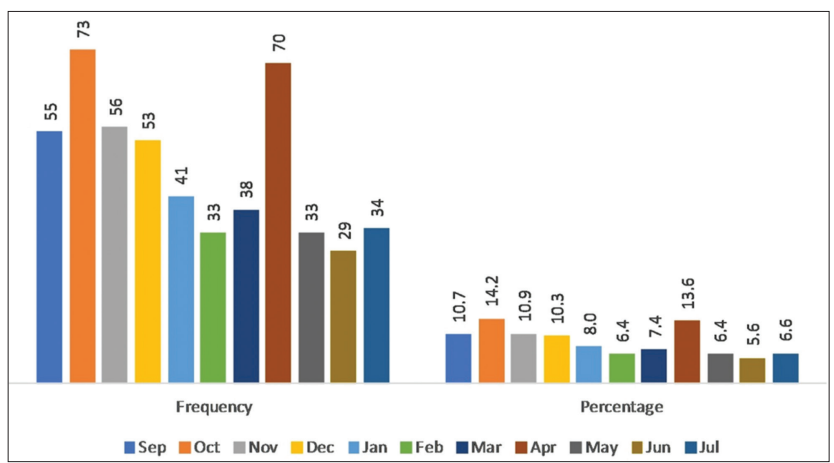

Figure-2: Monthly distribution of clinical cases of young dogs.

\section{Infectious diseases}

\section{Parvovirosis}

Canine parvovirus, contagious acute enteritis, occurred more commonly in dogs younger than 3 months of age in the current study which might be due to insufficient immunity (Table-2) [12]. On the other hand, a highly significant $(\mathrm{p}=0.000)$ association was observed between the breeds and occurrence of parvovirus.

\section{Ehrlichiosis}

Breed-wise incidence of ehrlichiosis was recorded higher in American Staffordshire Terrier. This observation was in agreement with the findings of Lakshmanan [13] who reported a higher prevalence of ehrlichiosis in purebred dogs. Therefore, this discrepancy in the breed predisposition might be due to immunological competence and susceptibility of different breeds to tick infestation [14]. Even that all breeds are prone to ehrlichiosis, some breeds such as German Shepherd dogs are more predisposed due to the inherent breed inability of blast formation [15]. Moreover, results suggested that there was no association between the occurrences of ehrlichiosis with sex, age, or season.

\section{Respiratory tract (RT) infections}

The RT is constantly exposed to infectious agents that can reach the upper and lower RT. Disease prevalence of the respiratory system in the present study was $0.97 \%$ close to that reported in a previous study [16]. The data analyzed found no association between the infection and different parameters.

\section{Eye disorders}

The reported prevalence of eye problems, in this study, was $5.24 \%$ in young dogs that agreed with the

Table-2: Age distribution of clinical conditions of young dogs.

\begin{tabular}{|c|c|c|c|c|}
\hline \multirow[t]{2}{*}{ Clinical condition } & \multirow[t]{2}{*}{ Total n (\%) } & \multicolumn{2}{|c|}{ Age } & \multirow[t]{2}{*}{ p-value } \\
\hline & & 1-3 months $n(\%)$ & $>3$ months $n(\%)$ & \\
\hline \multicolumn{5}{|l|}{ Infectious } \\
\hline Parvovirosis & $54(10.49)$ & $38(70.37)$ & $16(29.63)$ & $0.049 *$ \\
\hline Ehrlichiosis & $11(2.14)$ & $3(27.27)$ & $8(72.73)$ & 0.400 \\
\hline RT infections & $5(0.97)$ & $4(80.00)$ & $1(20.00)$ & 0.545 \\
\hline Eye disorders & $27(5.24)$ & $9(33.33)$ & $18(66.67)$ & 0.277 \\
\hline Endoparasitic I & $60(11.65)$ & $60(100.00)$ & $0(0.00)$ & $0.000 *$ \\
\hline Ectoparasitic I & $106(20.58)$ & $50(47.17)$ & $56(52.83)$ & 0.784 \\
\hline Subtotal & $263(51.07)$ & $164(62.36)$ & $99(37.64)$ & \\
\hline \multicolumn{5}{|l|}{ Non-infectious } \\
\hline Hip dysplasia & $11(2.14)$ & $1(9.09)$ & $10(90.91)$ & 0.069 \\
\hline Traumatic injuries & $117(22.72)$ & $47(40.17)$ & $70(59.83)$ & 0.150 \\
\hline NSH & $40(7.77)$ & $33(82.50)$ & $7(17.50)$ & $0.004 *$ \\
\hline Congenital anomalies & $15(2.91)$ & $8(53.33)$ & $7(46.67)$ & 1.000 \\
\hline Subtotal & $183(35.54)$ & $89(48.63)$ & 94 (51.37) & \\
\hline \multicolumn{5}{|l|}{ Non-specific } \\
\hline Gastroenteritis & $69(13.40)$ & $33(47.83)$ & $36(52.17)$ & 0.866 \\
\hline Subtotal & $69(13.40)$ & $33(47.83)$ & $36(52.17)$ & 0.866 \\
\hline Grand total & $515(100.00)$ & $286(55.53)$ & $229(44.47)$ & 0.081 \\
\hline
\end{tabular}

$\mathrm{RT}=$ Respiratory tract, NSH $=$ Nutritional secondary hyperparathyroidism, I = Infections. Asterisks (*) indicate a significant association 
results of Sarker et al. [16]. It affects males as well as females, regardless of age and season. It is rare that gender factor involves in the incidence of these kinds of pathologies and a few ocular diseases are specific to young dogs; still, it may occur at any age, except for glaucoma, which is almost reserved for older animals [17].

\section{Endoparasitic infections}

The prevalence of endoparasites found in this study was $11.65 \%$. According to other studies, the estimated worldwide prevalence of endoparasitic infections varies from $5 \%$ to $70 \%$ [18]. Therefore, for young dogs, the prevalence of $3.84 \%$ and $20 \%$ were recorded in Bangladesh and Nigeria, respectively $[11,18]$. This difference depends on many factors such as the geographical location, sampling protocols, and anthelmintic usage. Moreover, this study demonstrated that young dogs aged between 1 and 3 months are more likely to be infected with helminths and protozoa than older dogs $(p=0.000)$. It conforms to the earlier studies where infections with Toxocara canis, Isospora spp., and Giardia spp. represent the highest rates between the 6- and 12-week-old pups which are partially due to transmammary and lactogenic transmission [19]. On the basis of breed, the result showed that the American Staffordshire Terrier had higher prevalence rates of endoparasites $(33.33 \%)$ than the mixed breeds (20\%) and Rottweiler (20\%). Analysis showed a strong association $(\mathrm{p}=0.000)$ between breeds and the prevalence of endoparasites. American Staffordshire Terrier and Rottweiler may be less immune to the parasites than the mixed breeds.

On the other hand, mixed breeds are usually more free to roam from one place to another, and therefore get exposed [20]. Nevertheless, no significant breed difference was found in another study [21].

\section{Ectoparasitic infections}

Ectoparasitic infections were recorded on 57 male dogs (53.77\%) and 49 female dogs (46.23\%). Nevertheless, no statistically significant difference was observed between host gender and ectoparasite infestation (Table-3). Similar findings were reported in other studies $[22,23]$. Although ectoparasites were noted in young dogs throughout all the period of the study, they were more prevalent in the wet season, with a significant association between season and infestation (Table-4). This seasonal influence was observed in other countries as well [24]. It could be associated with variations in temperature and humidity required for ectoparasite survival and reproduction, which may vary between geographical regions. On the other hand, dogs kept indoors are less exposed to ectoparasites compared to hunting dogs [25]. However, these two categories were equally affected in the current study. Furthermore, compared to purebred dogs, mixed breed dogs were less infested (79.25\% vs. $20.75 \%)$.

\section{Non-infectious diseases}

\section{Hip dysplasia}

Hip dysplasia, a common developmental disorder, had affected 11 male dogs $(100 \%)$ in the present study, compared to other studies where only $59.55 \%$ of male dogs were affected [26]. This could be related to over breeding, which leads to the occurrence of hip dysplasia or to the fact that male neutered dogs may be at increased risk for the development of hip dysplasia than females, especially of neutering at

Table-3: Sex distribution of clinical conditions of young dogs.

\begin{tabular}{|c|c|c|c|c|}
\hline \multirow[t]{2}{*}{ Clinical condition } & \multirow{2}{*}{$\begin{array}{l}\text { Total } \\
\text { n (\%) }\end{array}$} & \multicolumn{2}{|c|}{ Sex } & \multirow[t]{2}{*}{ p-value } \\
\hline & & $\begin{array}{c}\text { Female } \\
\text { n (\%) }\end{array}$ & $\begin{array}{c}\text { Male } \\
\text { n (\%) }\end{array}$ & \\
\hline \multicolumn{5}{|l|}{ Infectious } \\
\hline Parvovirosis & $54(10.49)$ & $22(40.74)$ & $32(59.26)$ & 0.440 \\
\hline Ehrlichiosis & $11(2.14)$ & $6(54.55)$ & $5(45.45)$ & 1.000 \\
\hline RT infections & $5(0.97)$ & $2(40.00)$ & $3(60.00)$ & 1.000 \\
\hline Eye disorders & $27(5.24)$ & $13(48.15)$ & $14(51.85)$ & 1.000 \\
\hline Endoparasitic I & $60(11.65)$ & $25(41.67)$ & $35(58.33)$ & 0.464 \\
\hline Ectoparasitic I & $106(20.58)$ & $49(46.23)$ & $57(53.77)$ & 0.680 \\
\hline Subtotal & $263(51.07)$ & $117(44.49)$ & $146(55.51)$ & \\
\hline \multicolumn{5}{|l|}{ Non-infectious } \\
\hline Hip dysplasia & $11(2.14)$ & $0(0.00)$ & $11(100.00)$ & $0.014 *$ \\
\hline Traumatic injuries & $117(22.72)$ & $50(42.74)$ & $67(57.26)$ & 0.296 \\
\hline $\mathrm{NSH}$ & $40(7.77)$ & $16(40.00)$ & $24(60.00)$ & 0.500 \\
\hline $\begin{array}{l}\text { Congenital } \\
\text { anomalies }\end{array}$ & $15(2.91)$ & $3(20.00)$ & $12(80.00)$ & 0.135 \\
\hline Subtotal & $183(35.54)$ & $69(37.70)$ & $114(62.30)$ & \\
\hline \multicolumn{5}{|l|}{ Non-specific } \\
\hline Gastroenteritis & $69(13.40)$ & $31(44.93)$ & $38(55.07)$ & 0.612 \\
\hline Subtotal & $69(13.40)$ & $31(44.93)$ & $38(55.07)$ & 0.612 \\
\hline Grand total & $515(100.00)$ & $217(42.14)$ & $298(57.86)$ & $0.012 *$ \\
\hline
\end{tabular}

RT = Respiratory tract, NSH = Nutritional secondary hyperparathyroidism, I = Infections. Asterisks (*) indicate a significant association 
Table-4: Season distribution of clinical conditions of young dogs.

\begin{tabular}{|c|c|c|c|c|}
\hline \multirow[t]{2}{*}{ Clinical condition } & \multirow{2}{*}{$\begin{array}{l}\text { Total } \\
\text { n }(\%)\end{array}$} & \multicolumn{2}{|c|}{ Season } & \multirow[t]{2}{*}{ p-value } \\
\hline & & $\begin{array}{c}\text { Wet (September-February) } \\
\text { n (\%) }\end{array}$ & $\begin{array}{c}\text { Dry (March-July) } \\
\text { n (\%) }\end{array}$ & \\
\hline \multicolumn{5}{|l|}{ Infectious } \\
\hline Parvovirosis & $54(10.49)$ & $33(61.11)$ & $21(38.89)$ & 0.333 \\
\hline Ehrlichiosis & $11(2.14)$ & $8(72.73)$ & $3(27.27)$ & 0.400 \\
\hline RT infections & $5(0.97)$ & $4(80.00)$ & $1(20.00)$ & 0.545 \\
\hline Eye disorders & $27(5.24)$ & $15(55.56)$ & $12(44.44)$ & 0.789 \\
\hline Endoparasitic I & $60(11.65)$ & $39(65.00)$ & $21(35.00)$ & 0.139 \\
\hline Ectoparasitic I & $106(20.58)$ & $72(67.92)$ & $34(32.08)$ & $0.012 *$ \\
\hline Subtotal & $263(51.07)$ & $171(65.02)$ & $92(34.98)$ & \\
\hline \multicolumn{5}{|l|}{ Non-infectious } \\
\hline Hip dysplasia & $11(2.14)$ & $9(81.82)$ & $2(18.18)$ & 0.193 \\
\hline Traumatic injuries & $117(22.72)$ & $64(54.70)$ & $53(45.30)$ & 0.515 \\
\hline $\mathrm{NSH}$ & $40(7.77)$ & $19(47.50)$ & $21(52.50)$ & 1.000 \\
\hline Congenital anomalies & $15(2.91)$ & $8(53.33)$ & $7(46.67)$ & 1.000 \\
\hline Subtotal & $183(35.54)$ & $100(54.64)$ & $83(45.36)$ & \\
\hline \multicolumn{5}{|l|}{ Non-specific } \\
\hline Gastroenteritis & $69(13.40)$ & $39(56.52)$ & $30(43.48)$ & 0.498 \\
\hline Subtotal & $69(13.40)$ & $39(56.52)$ & $30(43.48)$ & 0.498 \\
\hline Grand total & $515(100.00)$ & 310 (60.19) & $205(39.81)$ & $0.001 *$ \\
\hline
\end{tabular}

$\mathrm{RT}=$ Respiratory tract, NSH $=$ Nutritional secondary hyperparathyroidism, I = Infections. Asterisks $(*)$ indicate a significant association

an age younger than 6 months [26,27]. Still, multiple prevalence studies showed no sex predilection [28]. Besides, clinical signs are usually evident at 4-12-month-old dogs [29]; this explains the high incidence in the group of age older than 3 months (90.91\%). Nevertheless, no significant association was reported. Furthermore, any size or breed of dog can be affected; however, the condition is commonly evaluated in purebred and large breed to check the possibility of breeding. This explains the finding where German Shepherd, Rottweiler, and American Staffordshire Terrier represented $72.73 \%, 18.18 \%$, and $9.09 \%$, respectively $(p=0.027)$. On the other hand, season had a non-significant effect on the distribution of such condition.

\section{Traumatic injuries}

Young dogs are faced with dangers and traumatic injuries from a minor wound to fracture. However, a breed distribution was observed (Table-1). This is in part due to population distribution to the owner's preference. Nevertheless, no association between clinical cases and other parameters has been established.

\section{$\mathrm{NSH}$}

This metabolic condition is caused by a high dietary intake of phosphorus and chronic decrease in calcium. Puppies and large breeds were found to be, especially, susceptible to it due to the high calcium requirement $[30,31]$. This observation agrees with the current study where the highest occurrence was recorded in American Staffordshire Terrier.

\section{Congenital anomalies}

Usually, congenital anomalies tend to manifest after some time and so quite frequently a delay in consulting to the veterinarian since no subtle signs are there. Interestingly, in the current study, some cases of congenital anomalies were reported in $2.91 \%$ of cases.

\section{Non-specific diseases}

\section{Gastroenteritis}

The present work showed that gastroenteritis had a prevalence of $13.40 \%$ of the total diseased young dogs. Contrarily, other findings had reported a prevalence of $52 \%$ in Turkey and 56.5\% in Egypt $[32,33]$. This could be explained to a difference in geographical distribution. Besides, no association between the age and frequency of gastrointestinal disorders was reported in the current study. This result is in accordance with Hubbard et al.[34].

\section{Conclusion}

The present study was the first recorded data about the prevalence of clinical conditions in young dogs admitted to the National School of Veterinary Medicine clinic, Tunisia, during the period from September 2012 to July 2013. It was concluded that traumatic injuries, ectoparasitic infections, and gastroenteritis were the major health issue among young dogs. Sex, breeds, and season had a significant effect on the distribution of juvenile canine diseases. Therefore, medical awareness of the owners should be increased to improve the ectoparasites control measures, deworming procedure, and vaccination status as well as to dedicate adequate attention to young dogs.

\section{Author's Contributions}

GT was responsible for all parts of this study. The author read, finalized, and approved the manuscript. 


\section{Acknowledgments}

The author is thankful to the National School of Veterinary Medicine, Manouba University, Tunisia, for allowing to carry out the research work at the clinic. This study did not receive any fund or grant.

\section{Competing Interests} interests.

The author declares that he has no competing

\section{Publisher's Note}

Veterinary World remains neutral with regard to jurisdictional claims in published institutional affiliation.

\section{References}

1. Weston, M.A., Fitzsimons, J.A., Wescott, G., Miller, K.K., Ekanayake, K.B. and Schneider, T. (2014) Bark in the park: A review of domestic dogs in parks. Environ. Manage., 54(3): 373-382.

2. Okusanya, P.O., Jagun, A.J.J., Adeniran, G.A., Emikpe, B.O. and Jarikre, T. (2014) Retrospective study of diseases and associated pneumonia type diagnosed in dogs at post-mortem at the veterinary teaching hospital, Ibadan, Nigeria. Sokoto J. Vet. Sci., 12(3): 15-20.

3. Rage. Rage Bulletin (2016) Available from: http:// www.rage.tn/Fr/image.php?id=498. Last accessed on 09-04-2018.

4. Herron, M.E., Kirby-Madden, T.M. and Lord, L.K. (2014) Effects of environmental enrichment on the behavior of shelter dogs. J. Am. Vet. Med. Assoc., 244(6): 687-692.

5. Day, M.J. (2007) Immune system development in the dog and cat. J. Comp. Pathol., 137(Suppl-1): S10-S15.

6. Kennedy, L.J., Barnes, A., Happ, G.M., Quinnell, R.J., Bennett, D., Angles, J.M., Day, M.J., Carmichael, N., Innes, J.F., Isherwood, D., Carter, S.D., Thomson, W. and Ollier, W.E. (2002) Extensive interbreed, but minimal intra breed, variation of DLA class II alleles and haplotypes in dogs. Tissue Antigens, 59(3): 194-204.

7. Rijnberk, A. and Stokhof, A.A. (2009) General examination. In: Rijnberk, A. and van Sluijs, F.J., editors. Medical History and Physical Examination in Companion Animals. $2^{\text {nd }}$ ed. Saunders Elsevier, China. p47-62.

8. Parvez, A., Prodhan, A.M., Das, B.C. and Khatun, R. (2014) Prevalence of clinical conditions in dogs and cats at teaching veterinary hospital (TVH) in Chittagong veterinary and animal sciences university, Bangladesh. Res. J. Vet. Pract., 2(6): 99-104.

9. Gosling, S.D., Carson, J.S. and Potter, J. (2010) Personalities of self-identified dog people and cat people. Anthrozoos, 23(3): 213-222.

10. Summers, J.F., Diesel, G., Asher, L., McGreevy, P.D. and Collins, L.M. (2010) Inherited defects in pedigree dogs. Part 2: Disorders that are not related to breed standards. Vet. J., 183(1): 39-45.

11. Tarafder, A. and Samad, M.A. (2010) Prevalence of clinical diseases of pet dogs and risk perception of zoonotic infection by dog owners in Bangladesh. Bangladesh J. Vet. Med., 8(2): 163-174.

12. Mylonakis, M.E., Kalli, I. and Rallis, T.S. (2016) Canine parvoviral enteritis: An update on the clinical diagnosis, treatment, and prevention. Vet. Med. Res. Rep., 7(1): 91-100.

13. Lakshmanan, B. (2001) Diagnosis of Canine Ehrlichiosis Using Polymerase Chain Reaction. MVSc Thesis. The Tamil Nadu Veterinary and Animal Sciences University, Chennai, India.

14. Parmar, C., Pednekar, R., Jayraw, A. and Gatne, M. (2013) Comparative diagnostic methods for canine ehrlichiosis.
Turk. J. Vet. Anim. Sci., 37(1): 282-290.

15. Sainz, Á., Roura, X., Miró, G., Estrada-Peña, A., Kohn, B., Harrus, S. and Solano-Gallego, L. (2015) Guideline for veterinary practitioners on canine ehrlichiosis and anaplasmosis in Europe. Parasit. Vectors, 8(1): 75.

16. Sarker, M.S., Ahduzzman, M., Kabir, M.N., Rahman, M.K., Hossian, F., Nath, S.K. and Bupasha, Z.B. (2015) Prevalence of clinical conditions in dogs and cats at central veterinary hospital (CVH) in Dhaka, Bangladesh. Bangladesh Vet. J., 26(2): 101-105.

17. Hamilton, H.L. (1999) Pediatric ocular emergencies. Vet. Clin. North Am. Small Anim. Pract., 29(4): 1003-1021.

18. Odeniran, P.O. and Ademola, I.O. (2013) Prevalence of zoonotic gastrointestinal helminth in dogs and knowledge of risk of infection by dog owners in Ibadan. Niger. Vet. J., 34(3): 851-858.

19. Barutzki, D. and Schaper, R. (2013) Age-dependent prevalence of endoparasites in young dogs and cats up to one year of age. Parasitol. Res., 112 Suppl 1: 119-131.

20. Idika, I.K., Onuoraha, E.C., Obi, C.F., Umeakuana, P.U., Nwosu, C.O., Onah, D.N. and Chiejina, S.N. (2017) Prevalence of gastrointestinal helminth infections of dog in Enugu State, South Eastern Nigeria. Parasite Epidemiol. Control, 2(3): 97-104.

21. Anosike, J., Nwoke, B., Ukaga, C., Madu, N. and Dozie, I. (2004) Aspects of intestinal helminth parasites of dogs in world bank-assisted housing estate, New Oweri, Nigeria. Afr. J. Appl. Zoo. Environ. Biol., 6(1): 25-29.

22. Ebrahimzade, E., Fattahi, R. and Ahoo, M.B. (2016) Ectoparasites of stray dogs in Mazandaran, Gilan and Qazvin Provinces, North and center of Iran. J. Arthropod Borne Dis., 10(3): 364-369.

23. Abuzeid, M.I.A., Sallam, N.H., Youssef, M.E., El-Gayar, K.A., Aal, A.A.A. and El-Gawady, M.H. (2015) Studies on ectoparasites of stray dogs in Ismailia city. Egypt. Vet. Med. Soc. Parasitol. J., 11(1): 115-122.

24. Xhaxhiu, D., Kusi, I., Rapti, D., Visser, M., Knaus, M., Lindner, T. and Rehbein, S. (2009) Ectoparasites of dogs and cats in Albania. Parasitol. Res., 105(6): 1577-1587.

25. Shukullari, E., Rapti, D., Visser, M., Pfister, K. and Rehbein, S. (2017) Parasites and vector-borne diseases in client-owned dogs in Albania: Infestation with arthropod ectoparasites. Parasitol. Res., 116(1): 399-407.

26. Simon, S., Ganesh, M.R., Ayyappan, S., Rao, G.D., Kumar, R.S., Manonmani, M. and Das, B.C. (2010) Incidence of canine hip dysplasia: A survey of 272 cases. Vet. World, 3(5): 219-220.

27. Witsberger, T.H., Villamil, J.A., Schultz, L.G., Hahn, A.W. and Cook, J.L. (2008) Prevalence of and risk factors for hip dysplasia and cranial cruciate ligament deficiency in dogs. J. Am. Vet. Med. Assoc., 232(12): 1818-1824.

28. Hou, Y., Wang, Y., Lu, X., Zhang, X., Zhao, Q., Todhunter, R.J. and Zhang, Z. (2013) Monitoring hip and elbow dysplasia achieved modest genetic improvement of $74 \mathrm{dog}$ breeds over 40 years in USA. PLoS One, 8(10): e76390.

29. Syrcle, J. (2017) Hip dysplasia: Clinical signs and physical examination findings. Vet. Clin. North Am. Small Anim. Pract., 47(4): 769-775.

30. Palmer, N. (1993) Metabolic diseases of bones. In: Jubb, K.V.F., Kennedy, P.C. and Palmer, N., editors. Pathology of Domestic Animals. $4^{\text {th }}$ ed., Vol. 1. Academic Press, California. p55-93.

31. Svoboda, M., Doubek, J. and Zert, Z. (1994) Secondary hyperparathyroidism in dogs. Vet. Med. (Praha), 39(1): 29-36.

32. Rakha, G.M., Abdl-Haleem, M.M., Farghali, H.A. and Abdel-Saeed, H. (2015) Prevalence of common canine digestive problems compared with other health problems in Teaching Veterinary Hospital, Faculty of Veterinary Medicine, Cairo University, Egypt. Vet. World, 8(3): 403-411. 
33. Ylmaz, Z., Kennerman, E., Senturk, S., Temizel, M. and Aytug, N. (2002) The evaluation of cats and dogs referred to the Clinics of Companion Animals- Internal Medicine, Veterinary Faculty, University of Uludag (1999-2000). Vet.
Fak. Derg. Uludag Univ., 21(1/3): 23-31.

34. Hubbard, K., Skelly, B.J., Mckelvie, J. and Wood, J.L. (2007) Risk of vomiting and diarrhea in dogs. Vet. Rec., 161(22): 755-757.

$* * * * * * * *$ 